\title{
Association of Sequence types, Antimicrobial Resistance and Virulence Genes in India isolates of Klebsiella pneumoniae: A Comparative Genomics Study
}

Abhirami Krishnamoorthy Sundaresan

SASTRA Deemed to be University

Keerthana Vincent

SASTRA Deemed to be University

Ganesh Babu Malli Mohan ( $\nabla$ ganeshbmm@scbt.sastra.edu )

SASTRA Deemed to be University

Jayapradha Ramakrishnan ( $\sim$ kavijayashal@gmail.com )

SASTRA Deemed to be University

\section{Research Article}

Keywords: K. pneumoniae, Comparative Genomics, AMR, Virulence, Phylogeny

Posted Date: September 25th, 2021

DOI: https://doi.org/10.21203/rs.3.rs-923160/v3

License: (c) (i) This work is licensed under a Creative Commons Attribution 4.0 International License. Read Full License 


\section{Abstract}

Klebsiella pneumoniae is an important ESKAPE pathogen that causes sepsis, urinary tract infections, peritonitis, intraabdominal abscesses and upper respiratory infections. The strains exhibiting multidrug resistance and hypervirulence are priority pathogens for which immediate treatment and dissemination prevention strategies are required. The hypervirulent drug resistant $K$. pneumoniae is associated with high mortality rates. Numbers of environmental strains also have acquired virulence genes. Hence to gain a better understanding of the spread of antimicrobial resistant genes across the country over 10 years and to delineate environmental and clinical $K$. pneumoniae, a comparative genomics investigation was made. This is the first comparative genomic study using India isolates of $K$. pneumoniae, which includes publicly available WGS of 144 clinical and 9 environmental strains collected during 2010-2020. The blaCTX-M-15 was widely distributed in clinical isolates since 2013 and increased over time from $5 \%$ to $30 \%$. The co-existence of blaNDM and blaOXA was observed in $22 \%$ of clinical strains. Diverse serotypes were found among the $153 \mathrm{~K}$. pneumoniae isolates, of which, K51 (28\%) and K64 (21.56\%) were majorly found. Most of the K51 isolates belong to ST231 (93.02\%). And more than 50\% of KL51 strains were found to have both $r m p A$ and $m a g A$. The number of associated virulence genes ( $r m p A$, magA, entB, ybtS, iutA, alls, ) appeared to be higher in ST231-KL51 and ST23-KL1 isolates. Of greatest concern, these virulence genes are observed in environmental strains aswell. More than $97 \%$ of clinical strains have $y b t S$, iutA genes. Importantly, $98 \%$ of ESBL and $62 \%$ of carbapenamase isolates harbored ybtS, iutA and rmpA, $m a g A$ respectively. The IncF conjugative plasmids are predominant in K. pneumoniae, which contribute to the spread of antimicrobial resistant and virulence genes. The increasing trend in hypervirulent strains was observed from 2017. The phylogenetic analysis separates the environmental from clinical strains and is characterized by uncommon STs and serotypes. Thus, the study illustrates the K. pneumoniae genomic surveillance in India representing the phylogenetic evolution, STs, AMR, virulence, serotype to provide more attention for immediate treatment and preventing the dissemination of $K$. pneumoniae.

\section{Introduction}

Klebsiella pneumoniae has a strong association with human as resident flora and colonizes almost every part of the human body with most preferential in the respiratory, gastrointestinal, and urinary tract (Paczosa \& Mecsas, 2016). The other predominant habitats include soil, plants, surface water, sewage, industrial effluent, etc. (Parkinson et al., 2007; Bagley, 2014). Despite the source of origin, clinical isolates causing nosocomial and community acquired infections. This leads to serious therapeutic threats given the increase in drug resistant phenotypes and decrease in effective antibiotics. The emergence and spread of extensive drug resistant $K$. pneumoniae are global concern, which causes severe untreatable infections in immunocompromised patients (Bertelli et al., 2019; Lee et al., 2017). The associated character of antibiotic resistance and virulence in $K$. penumoniae was reported to have high morbidity and mortality rates in immunocompetent individuals aswell (Effah et al., 2020). Pneumonia, meningitis, urinary tract infections, and bloodstream infections are the potential illness caused by this bacterium in immunocompromised (Paczosa \& Mecsas, 2016). To treat these infections, similar classes of antibiotics 
are been in use for the last 2 decades, that render the bacterium to evolve strategies to survive in antibiotic stress environment (Roemhild \& Schulenburg, 2019). Few potential survival strategies include acquisition of new AMR genes, production of hydrolytic enzymes, expression of efflux proteins, and formation of biofilm (Uruén et al., 2021; Ni et al., 2020). The majority of AMR genes are acquired through conjugation, transformation, and transduction. Hence understanding the co-occurrence of plasmid type and antimicrobial resistance (AMR) gene transfer could help to limit the dissemination of AMR and virulence genes. Nevertheless, antibiotic resistance is not confined to clinical strains alone, it is also widespread among the non-pathogenic environmental isolates (Peterson \& Kaur, 2018). Some important virulence factors of $K$. pneumoniae include capsular polysaccharide, siderophores, fimbriae etc. (Zhu et al., 2021). However, few factors are common in both clinical and environmental isolates such as capsule, type 1 fimbriae, type 3 fimbriae and siderophores.

K. pneumoniae are classified into classical strain (cKp) and hypermucous strain (hvKp) (Russo \& Marr, 2019). The hvKp is significantly different from the cKp by harbouring $r m p A$ and $r m p A 2$ mucus-regulator genes, K1, K2, K20 capsular types and aerobactin gene (Russo \& Marr, 2019). The hvKp strains can cause serious infections such as liver abscess and meningitis in both immunocompetent and immunocompromised individuals (Serban et al., 2021). Also, hvKp strains are characterized by increased resistance to host defense mechanism and are associated with high mortality rates (Shon et al., 2013). Both cKp and hvKp are known to possess high diversity of antimicrobial resistance genes, with increased resistance towards 3rd generation cephalosporin (Xie et al., 2018). The combination of drug resistance and hypervirulence advocates $K$. pneumoniae as a clinically significant pathogen of global health concern. Also, K. pneumoniae is listed in WHO priority critical pathogens. As the hypervirulent and drug resistant population remains to overlap in most isolates, it is necessary to identify the distinguishing features of pathotypes and environmental isolates of $K$. pneumoniae to prevent the spread of pathogenic strains in hospital and community settings.

The traditional taxonomic techniques, $16 \mathrm{~S}$ gene Sanger sequencing, and PCR-based sequence typing (MLST) are all well-established in characterizing pathogenic bacteria (Linxiang Chen et al., 2014).

However, these techniques are unable to distinguish closely related species as well as limited in detecting diverse AMR genes and virulome. Recent advancements in the next generation sequencing and extended applications of bioinformatics tools facilitate gathering information on thousands of bacterial species on their virulence genes, resistance genes, and genetic relationship (Hendriksen et al., 2019). In the present study, comparative investigations on the distinctive features of $K$. pneumoniae were studied. We retrieved 153 genomes of clinical and environmental K. pneumoniae isolates of India origin from PATRIC and comparative genomic analyses were made to understand the spread of $K$. pneumoniae resistant strains across the country over 10 years. Followed by, sequence types (ST), evolutionary relationships, the resistance mechanisms, acquisition of AMR genes, presence of conjugative and non-conjugative plasmids and virulence genes were screened. In addition, the association between the four major factors such as virulence, resistance determinants, replicon types and ecological niche were studied for 153 genomes of $K$. pneumoniae. The genomic surveillance is conducted to gain insights into genotypic 
characterization which may facilitate immediate treatment and attention to prevent the dissemination in the environment and clinical settings.

\section{Materials And Methods}

\section{Retrieval of 153 genome sequence data}

The Whole Genome Sequence (WGS) of 153 India isolates of K. pneumoniae were collected from the PATRIC database (The Pathosystems Resource Integration Center) (Wattam et al., 2018). We retrieved the assembled FASTA sequence which were previously assembled using Spades. These strains were sequenced using Illumina, Nanopore and PacBio sequencing platform and shown in the Supp. table-1. The ST type, year of strain isolation and sampling source, genome size and GC content of the isolates were collected from the PATRIC.

\section{Antimicrobial Resistance profiling}

AMR profiles of each isolate were carried out using, Resfinder 4.1 in the CGE database (Kwon et al., 2016). A total of eight antibiotic classes such as $\beta$-lactam, aminoglycoside, fluoroquinolone, fosfomycin, sulfonamide, macrolide, phenicol and rifamycin were selected. For AMR profiling, 88 AMR genes belonging to these classes were taken. Followed by, the resistance mechanism of 153 isolates was analyzed using CARD (Comprehensive Antibiotic Resistance Database) (McArthur et al., 2013).

\section{Virulome analysis}

VFDB (Virulence factor database) was used to screen the virulence genes. This tool allows the identification of type I fimbriae genes ( $f ı m D, f i m K, f i m H, f i m C)$, type III fimbriae genes ( $m r k D, m r k J, m r k F$, $m r k C, m r k A, m r k l)$, siderophore genes (iutA, entB, ybtS), allantoin utilization gene (allS), capsular genes ( $w c a H, w c a G, \operatorname{manB}, \operatorname{manC}$, hcaA, wcbR, rmpA and magA), type IV pili (tapQ, pilJ). type III secretion system (vopB2) and type IV secretion system (clpV/tssh) [http://www.mgc.ac.cn/VFs/] (Kwon et al., 2016).

\section{Serotype analysis}

To screen the type of serotype, Kaptive database was used (Wyres et al., 2019). Using this type K-locus types were predicted.

\section{Plasmid profiling}

Plasmid finder was utilized to identify plasmids that are found in the genome sequence. The FASTA format was used to identify the replicon sequence that matched with $100 \%$ identity (Carattoli et al., 2014).

\section{Phylogenetic analysis}


The evolutionary relationships among the 153 K. pneumoniae were determined using CSI Phylogeny. To investigate the phylogenetic placement based on MLST, the seven housekeeping genes were concatenated for each genome and a reference strain, MGH 78578 (Kumar et al., 2011) using MegaX. Neighbor-joining method was used to view the tree with bootstrap value 1000 . Tree editing and annotation were performed using interactive Tree of Life (iTOL) (Nicolás et al., 2018).

\section{Results}

\section{Overview of the Genomic metadata Composition of $K$. pneumoniae isolates}

The PATRIC metadata depicts 144 clinical strains and 9 environmental strains. The isolation source of strains are blood $(n=115)$, urine $(n=9)$, endotracheal aspirate $(n=5)$ bronchoalveolar lavage $(n=4)$, sputum $(n=4)$, pus $(n=3), \operatorname{CSF}(n=2)$, nasal swab $(n=2)$, rhizosphere soil $(n=1 ; A W D 5)$, root nodule ( $n=1 ; H P C N 22)$, domestic sewage ( $n=2 ; \operatorname{HPCN5}$, HPCN17), STP sludge $(n=1 ; P V N-1)$, endophyte $(n=1 ;$ ME30), river surface water ( $n=1 ; P L 1-R C S 238)$, industrial waste water ( $n=1 ;$ EGD-HP19), agriculture field soil $(n=1 ; K B G 6.2)$ (Supp.table 1). The genomic characterization of $K$. pneumoniae was performed as first part of the study. From the PARTIC database, we found these genomes were sequenced majorly by illumina and ion torrent. The genomes of study strains ranged in size from 4.4 Mbp to 6.3 Mbp and GC contents were between 55$57 \%$.

\section{Sequence type}

The study isolates were found to have 37 different STs, suggesting its diversity in India isolates. We found ST231 was predominant ( $n=43)$ among clinical strains. Followed by, ST147 ( $n=15)$, ST14 $(n=15)$, ST2096 ( $n=11)$, ST395 ( $n=9)$, ST43 ( $n=8)$, ST $11(n=7)$, ST23(n=6), ST16 $(n=6)$, ST15 $(n=3)$, ST437 $(n=2)$, other clinical strains comprised individual STs, ST13, ST42, ST101, ST307, ST557, ST570, ST628, ST3249, ST711, ST660, ST3836, ST3835, ST3789, ST3607, ST3605, ST4847, ST2816, ST3249. The scatter plot represents the distribution of STs, where ST231, ST147, ST2096 emerged and displayed with increasing trends during 2013, 2015 and 2018 (Figure 1). Among these, ST14 was common across all years. The environmental strains comprised of individual STs namely, ST22, ST200, ST555, ST1107, ST1728, ST2701, ST3689.

\section{Phylogenetic analysis}

The WGS of study strains were used for the phylogenetic analysis based on MLST (Suppl. Figure 1) and Single nucleotide polymorphism (Figure 2). The midpoint was divided into 2 major clades and further delineated into many clusters of $K$. pneumoniae. The environmental strain HPCN5, HPCN17, HPCN22, PL1-RCS238, AWD5, KBG6.2, EGD-HP19 were grouped in clade 1, whereas ME30 the endophyte isolate aligned in clade 2 , suggesting the evolution as a separate ancestral group. The reference strain MGH78578 was closely aligned with environmental strain PVN1, STP sludge isolate. The environmental strains were identified on a separate branch of the clusters consisting of clinical strains. 


\section{K. pneumoniae has a high prevalence of $\beta$-lactam and fluoroquinolone resistance}

Using the ResFinder and CARD databases, 88 different predominant AMR genes involved in 8 antibiotic classes were selected for AMR profiling. The resistance was found as follows, fosfomycin $100 \%(n=153)$, $\beta$-lactam $96 \%(n=147)$, fluoroquinolone $92 \%(n=142)$ followed by aminoglycoside $84 \%(n=129)$, sulfonamide $79.08 \%(n=121)$, phenicol $70 \%(n=107)$, macrolide $64.04 \%(n=98)$, rifamycin $48 \%(n=74)$. AMR genes associated with fosfomycin (FosA-like), $\beta$-lactam (blaCTX-M-15, blaTEM-1B), fluoroquinolone (oqXA-like, oqXB-like) aminoglycoside ( $\operatorname{aad} A 2$, $\operatorname{aac}\left(6^{\prime}\right) \mathrm{lb}$-cr-like) were predominant across the India strains (Suppl. Table 2).

To understand the distribution of AMR genes in 153 genomes during 2010-2020, Box and whisker plot was used (Figure 3). The data revealed the presence of a genome having a least of one $(n=1)$ and a maximum of $26(n=4)$ AMR genes. The average median distributions of 15 AMR genes/genome were noticed during 2013-2017.

Most commonly, $\beta$-lactamase genes blaCTX-M-15 $(\mathrm{n}=92)$, blaTEM-1B $(\mathrm{n}=87)$, carbapenamases blaOXA$232(\mathrm{n}=66)$, metallo- $\beta$-lactamase blaNDM-5 $(\mathrm{n}=29)$ and blaNDM-1 $(\mathrm{n}=10)$ were found among the study strains. blaNDM-5 exhibited co-positivity with blaCTX-M-15 and blaTEM-1B. The strains carrying blaCTXM-15, blaTEM-1B, and blaNDM-5 were increased from 2019.

Followed by, drug resistance mechanisms involved in study strains depicts antibiotic efflux $(57.51 \%$, $\mathrm{n}=88)$ and antibiotic inactivation by hydrolytic enzymes $(41 \%, \mathrm{n}=62)$ as predominant mechanisms. The major gene family observed for antibiotics efflux are resistance nodulation cell division (RND) (23\%, $n=35)$, major facilitator superfamily (MFS) $(18.95 \%, n=29)$ and ATP-binding cassettes (ABC) $(15.68 \%$, $\mathrm{n}=24)$. Similarly, in case of antibiotic inactivation, SHV $\beta$-lactamase gene family was prevalent $(26.79 \%$ $n=41)$ followed by, OXA- $\beta$-lactamase $(6.9 \%, n=10)$ and CTX-M- $\beta$-lactamase $(3.47 \%, n=5)$.

The predominant AMR gene in each 8 class of antibiotics was identified and screened its prevalence among 153 genomes. Such as, blaCTX-M-15 and blaTEM-1B ( $\beta$-lactam) aadA2 (Aminoglycoside) oqX-Alike and oqx-B-like (Fluoroquinolone) FosA-like: (Fosfomycin), erm(B)-like (Macrolide), sul1 (Sulfonamide), $A R R-2$ (Rifamycin), catA1like (Phenicol). About $9.8 \%$ of clinical isolates $(\mathrm{n}=15)$ were found to have all these 8 listed AMR genes, which are mostly belong to ST231.

The environmental strains also carried the blaSHV-1, FosA-like, efflux pump mediated resistance (oqx-A like, oqx-B-like). Notably, the industrial effluent isolate carried FosA-like, oqx-A-like, oqx-B-like, sul1, aac(6)lb-cr-like, blaSHV112, ere (A)-like, aacA4-like, aadA1.

\section{IncF-type conjugative plasmid is dominant among Klebsiella}

To understand the transmission of AMR determinants through plasmids, the type of plasmid and the resistance genes they carry were investigated. From the metadata, the number of plasmids estimated to be ranged from 1- 8 plasmids per strain, with most isolates harboring at least 2 plasmids. A clinical strain KpIMS38 isolated from pus harbored 16 plasmids. Followed by, the episome details of 153 strains were 
obtained using Plasmid finder. A total of 19 plasmid replicon types were detected from $93.4 \%(n=143)$ of isolates. The 19 plasmid replicon types are categorized as incompatibility plasmids (Inc) and mobilizable colicin plasmid (Col) groups. The most abundant epidemic plasmid is IncF-type conjugative plasmid $(80.39 \% \mathrm{n}=123)$ (Figure 5). Plasmids belonging to IncF-type are reported to carry ESBL genes, genes encoding carbapenemases, aminoglycoside modifying enzymes and quinolone resistance genes (Rozwandowicz et al., 2018). The colKP3 plasmid was identified in 83 isolates which is related to blaOXA232 and blaOXA-181 transfer. The second most prevalent were pKpQIL-IT plasmids $(n=75)$ belonging to IncFIB (pQIL) family carries an aminoglycoside resistance gene on a transposon-like element IS26. Both colKP3 and pKpQIL-IT plasmids were accompanied in 33.9\% $(n=52)$ isolates. These two dominant plasmids were not detected in any of the environmental strains. IncHI1B (pNDM-MAR) plasmid with NDM resistance was found in 33 clinical strains and an environmental strain. The colistin resistance genes (mcr1) encoding plasmids (IncX4, IncY) were detected only in three strains among 153 study isolates. Certain resistant genes blaCTX-M-15 (IncR, IncFIl, IncFII, IncHI1B, Col440I), blaNDM-5 (IncFII, IncX3) were detected in various plasmid replicon types. In the case of environmental strains, 5 isolates were harbored with one plasmid. The endophyte isolate has 2 plasmids possessing blaCTX-M-15, blaNDM, qnrB1, blaSHV-56, FosA, oqXA and oqxB resistant genes. The industrial effluent isolate has IncY, Phage-like plasmids encoding $m c r-1$ gene, we have also recorded the multiple resistance being carried by this isolate. In summary, clinical and environmental strains have plasmids encoding genes that confer resistance to $\beta$-lactam drugs, aminoglycoside, quinolone and colistin. The type, family and functions of plasmids are provided in Table 1.

\section{Correlation of Resistance and Plasmid type}

We narrowed down to identify the strains that carry predominant AMR genes among the 8 selected antibiotic classes $(n=15)$. These clinical isolates were found to have pKpQIL-IT and pKP3-A plasmid types. PKpQIL-IT carries aminoglycoside resistance gene on a transposon-like element IS26, a clinically important insertion sequence. pKP3-A, a mobilizable but non-self-conjugative plasmid is associated with bla-OXA-232 and blaOXA-181 genes.

\section{Associated virulence genes are higher in ST231 strains}

The presence of different virulence genes is shown in (Figure 4), which were screened using VFDB. Both clinical and environmental isolates were found to have genes involved in type1 fimbriae ( $f i m D$, fimK, fimH, fimC). Similarly, most isolates were detected with $m r k D, m r k J, m r k F, m r k C, m r k l, m r k A$ which are important genes for type 3 fimbriae. To identify the hypervirulent phenotypes, $r m p A$ a gene regulator for mucoid phenotype was analyzed. Nearly, $47 \%(n=77)$ of clinical and $33.3 \%(n=3)$ of environmental strains 
were identified as hypervirulent strains. Besides, the prevalence of magA gene (mucoviscocity associated gene) was comparatively less in clinical strains ( $n=56,38.8 \%)$ than the $r m p A$ genes. The magA was detected in environmental strains $(n=5,55.5 \%)$ as well. The presence of both $r m p A$ and magA genes was not detected in root nodule, STP sludge and agriculture field soil isolate. The co-occurrence of $r m p A$ and magA genes was observed in domestic sewage isolates $(n=2)$ and an industrial wastewater isolate $(n=1)$. Likewise, the $r m p A$ and $m a g A$ were accompanied in clinical strains $(n=38)$. These clinical strains were identified as blood isolates majorly with K51 serotype $(n=18)$. Among the study strains, $K 51(n=43)$ and K64 ( $n=33$ ) serotypes were majorly found. Yet, the K51 serotype was not associated with severe infections and a recent report has identified K64 belonging to ST11 as an emerging superbug worldwide (Zhao et al., 2020), however, none of the 153 Indian isolates were found to have K64-ST11.

The most reported hypervirulent K1 and K2 serotypes (Brisse et al., 2013) were less prevalent, $n=7$ and $\mathrm{n}=11$ respectively. The co-occurrence of $r m p A$ and $m a g A$ genes was observed in $\mathrm{K} 1(\mathrm{n}=6)$ and K2 $(\mathrm{n}=2)$ serotypes belong to ST23 and ST14 respectively.

Followed by, most important siderophores were screened. The three most important siderophores systems in Enterobacteriaceae are yersinibactin ( $y b t S)$, aerobactin (iutA) and enterobactin (entB). Hence the prevalence of these siderophore systems was analysed in K. pneumoniae strains. The entB was detected in all the study strains ( $n=153)$, ybtS gene was found in $98.6 \%$ in clinical $(n=142)$ and $77.7 \%$ in environmental strains $(n=7)$ and iutA gene were observed in $97.2 \%$ in clinical and $88.8 \%$ of environmental strains. The root nodule strain was negative for both $y b t S$ and iutA. In addition, allantoin utilization (allS) was screened in the study strains as it has been associated with hypervirulence (Shon et al., 2013). The allS gene was observed in $65.97 \%$ of clinical $(n=95)$ and $77.77 \%$ of environmental strains $(n=7)$. Further, the strains associated with hypervirulence factors ( $m a g A, r m p A$, allS, entB, ybtS, iutA), were identified in 3 environmental strains (EGD HP-19, HPCN17 and HPCN5) and 29 clinical strains. The number of associated virulence genes appeared to be high in strains ST231- K51 and ST23- KL1.

\section{Convergence of AMR and Virulence}

To investigate the relationship between AMR and virulence in K. pneumoniae, ESBL (blaCTX-M-15, blaTEM-1B) and carbapenamase (blaOXA-232) harboring isolates were mapped with major virulence genes ( $r m p A$, magA, ybtS, alls, iutA). $98 \%$ of the ESBL and $62 \%$ of carbapenamase isolates harbored $y b t S$, iut $A$ and $r m p A$, magA respectively. The positive correlation between resistance and virulence in $K$. pneumoniae seeks prominent attention in clinical settings.

\section{Discussion}

This is the first comparative genomic study of $K$. pneumoniae isolates from India, which includes WGS of 144 clinical and 9 environmental strains collected during 2010-2020. Here, we examined antibiotic resistance, diversity of STs, serotypes, virulence genes, plasmids and their evolutionary relatedness. 
Emerging drug resistant and virulent phenotypes of $K$. pneumoniae is a challenging concern worldwide. Prevalence of ESBL producing microorganism is increasing (Flokas et al., 2017; Kuralayanapalya et al., 2019). Nursing homes and intensive care units are the reservoirs of ESBL harboring microorganisms, mainly causing sepsis, urinary tract infections, peritonitis, intraabdominal abscesses, and upper respiratory infections (Sartelli et al., 2016; Lin et al., 2015; R. Podschun et al., 1998). The present analysis revealed the abundance of blood stream infections among Indian population in support with the previous report (Wyres et al., 2019). The AMR profile specified that fosfomycin (FosA) is widely distributed among all study strains including environmental isolates (100\%). However, the in vitro test demonstrates the susceptibility of fosfomycin, though FosA is widely found (Kopotsa et al., 2020). We observed second higher drug resistance to $\beta$-lactam antibiotics, most commonly carbapenem associated genes were detected. The prevalent ESBL types are SHV (sulfhydryl variable), CTX-M (cefotaximase) and TEM (Temoniera). Among these, CTX-M-type ESBLs are now found to be the most common type (Bradford, 2001). The blaCTX-M-15 was widely distributed in clinical isolates since 2013 and increased overtime from $5.45 \%$ to $30.43 \%$ during 2017 . As a result, blaCTX-M-15 renders high resistance to large $\beta$-lactam agents. The OXA type ESBLs are found in 125 strains with the highest occurrence of blaOXA232 $(n=66)$. These blaOXA232 producers belong to ST231 $(n=31)$, ST14 $(n=8)$, ST2096 $(n=8)$. The coexistence of blaNDM and blaOXA was reported to have resistance to all $\beta$-lactam antibiotics (Naha et al., 2021). In the present analysis, we observed the associated blaNDM and blaOXA in $22.22 \%$ of clinical strain. Further, among the study, we identified, 4 clinical strains harbored with a high number of AMR genes $(n=26)$. Two of these strains belong to ST14 and each of ST147 and ST437. These highly drug resistant strains harbored 4 important plasmid types of pK245 (blaCTX-M-15), pKP3-A (blaOXA-232, blaOXA-181), pKPN-IT (conjugative plasmid aadA2, blaOXA-1, qnrB1, sul1), pCROD2, (MCR-1 carrying conjugative plasmid), pKpQIL-IT (aminoglycoside resistance gene on a transposon-like element IS26), pVM01 (hot spot bearing plasmid, blaOXA-181) suggesting the role of plasmid in multiple antibiotic resistance and transfer.

Capsular polysaccharide is the major virulence factor, which protects the bacteria from intracellular killing, phagocytosis, serum complement proteins and oxidative stress conditions (Marcoleta et al., 2018; Cortés et al., 2002). Looking across the Kaptive data set of 153 genomes, we found 29 serotypes among the K. pneumonaie isolates of which, K51 (28.1\%) and K64 (21.56\%) were majorly found. Most of the K51 isolates belong to ST231 (93.02\%) and K64, which are distributed diverse among major clonal types of ST14, ST147, ST395, ST2096 and ST231. Capsular types KL1, KL2, K5 K20 K57, are considered markers for hvKp strains (Shon et al., 2013; Yu et al., 2008). However, they are less prevalent among our study population (Suppl. table 3). In line with the previous report KL1 and KL2 isolates belong to ST23 $(n=6)$ and ST14 $(n=10)$ respectively. The environmental strains have identified with non-major serotypes such as $\operatorname{KL} 16(n=3), \operatorname{KL3}(n=2), \operatorname{KL} 116(n=2), K L 9(n=1), K L 166(n=1)$. We then correlated the presence of $r m p A$ and magA with capsular serotypes, where, $\mathrm{K} 1$ strains $(\mathrm{n}=7)$ were found to have both $r m p A$ and $m a g A$ $(\mathrm{n}=6)$ and five $\mathrm{K} 2$ strains were not detected with $r m p A$ and $m a g A$. This observation suggests that $\mathrm{K} 1 / \mathrm{K} 2$ isolates may partially correspond to hypervirulence. Also, more than $50 \%$ of KL51 strains were found to have both rmpA and magA recommending the hypervirulence characteristics of KL51. 
Other chromosomally encoded pathogenicity factors that enables the bacteria to establish infection and progression of the disease by evolving immune evasion strategies were included. These include type 1 fimbriae, type 3 fimbriae, type VI secretion system, type III secretion system translocator protein, type IV pilus secretion, Type IV pili, ferric aerobactin receptor, cytotoxic necrotizing factor 1 , allantion utilization (Parrott et al., 2021). EntB, YbtS, and iutA are the prevalent siderophore among K. pneumoniae (Highsmith \& Jarvis, 1985). They promote growth in the upper respiratory tract, lungs, and serum. $K$. pneumoniae producing both $y b t S$ and entB can cause pneumonia. In our study, both $y b t S$ and entB are prevalent among both clinical and environmental strains suggesting their role in the acquisition of nutrients from the environments. Also, allS gene is considered an important virulence determinant of $K$. pneumoniae and characterized as hvKp that causes pyogenic liver abscesses (Chou et al., 2004s; Martin \& Bachman, 2018). In our study population, allS is present in 95 clinical and 7 environmental strains. Similarly, the other virulence genes (type1 fimbriae, T3SS-translocator protein, fimbriae, PilQ, T4SS-pili) were present among all the study strains. The number of associated virulence genes ( $r m p A$, magA, entB, $y b t S$, iutA, allS) appeared to be higher in ST231-KL51 isolates and ST23-KL1 isolates (Figure 6). Environmental strains $(n=3)$ were found to have all the associated virulence genes. Discrimination of environmental and clinical strains is important in diagnosis and treatment. We categorize these strains as a true environment (root nodule, endophyte), and other may be originated from human or animals (domestic sewage, industrial wastewater, river surface water, STP sludge, rhizosphere soil, agriculture field). The genetic relationship of the isolates was analyzed based on SNP and MLST (Figure 6). Environmental isolates were out grouped. The MLST typing of environmental strains showed a diversity of sequence types, ST22, ST200, ST555, ST1107, ST1377, ST2701. These STs, except ST1377 were also reported to be associated in clinical strains (Zhou et al., 2015). Among these environmental strains, EDGHP19, the industrial wastewater isolate was found to have a high number of resistant genes (AMR genes $=9$ ) when compared with other strains. However, we have noticed fewer AMR genes $(<10)$ in clinical strains as well $(\mathrm{n}=20)$. oqx-A like, oqx-B-like and FosA-like are commonly distributed among the environmental strains.

The environmental strains have been identified with non-major type serotypes such as KL16, KL3, KL116, $\mathrm{KL9}, \mathrm{KL} 166, \mathrm{KL} 50$. The root nodule and domestic sewage isolates have KL5 serotype, which is also considered as a marker for hvKp. AWD5 and HPCN22 $(n=2)$ were not detected with $r m p A$ and magA genes. However, 49 clinical strains were also not detected with these two major virulent genes (Figure 6). Rhizosphere soil AWD5 K. pneumoniae is avirulent in the lung infection mice model (Rajkumari et al., 2021). The AMR and virulence characteristics are overlapped in both clinical and environment. Although the genomes of environmental strains collected in this study are not sufficiently conclusive to discriminate the $K$. pneumoniae from clinical settings and soil environments, some interesting observations were made. The phylogenetic analysis separates the environmental from clinical strains and we have noticed that environmental strains are characterized by uncommon STs and serotypes. The plasmids, pKpQIL-IT and colKP3 dominant in clinical strains are not detected in environmental strains.

\section{Conclusion}


Taken together, our analysis with 153 genomes of $K$. pneumoniae, revealed the abundance of bloodstream infections among Indian population. Most commonly, $\beta$-lactamase genes blaCTX-M-15, blaTEM-1B and blaOXA-232 were found among the study strains. blaNDM-5 exhibited co-positivity with blaCTX-M-15 and blaTEM-1B. Strains carrying blaCTX-M-15, blaTEM-1B, and blaNDM-5 were observed with a growing trend from 2019. The OXA type ESBLs are found in 124 strains with the highest occurrence of blaOXA-232, majorly belong to ST231. IncF conjugative plasmid is abundant followed by pKpQIL-IT and coIKP3. These dominant plasmids are not found in environmental strains. The clinical isolates that have both $r m p A$ and $m a g A$ were identified as blood isolates majorly with K51 serotype. Diverse ST types were noticed among which, ST231, ST14, ST147 are prevalent. The number of associated virulence genes ( $r m p A$, magA, entB, ybtS, iutA, iutA, allS) was found to be higher in ST231KL51 and ST23-KL1 isolates, whereas the environmental strains are characterized by uncommon STs and serotypes. The observation of convergence of resistance and virulence in $K$. pneumoniae is a major concern. Based on the present genomic investigations, we strongly suggest detection of $K$. pneumoniae strains with the genotype of ST231-KL51 and ST23-KL1 needs more attention for immediate treatment and preventing its dissemination.

\section{Declarations}

\section{Acknowledgment}

We thank the Science and Engineering Research Board (SERB), Department of Science and Technology, New Delhi for funding (EMR/2016/007613). We thank SASTRA Deemed University for providing the research facilities and infrastructure. We sincerely thank CMC, Vellore and other Indian institutions for providing public availability of Klebsiella genomes.

\section{Ethics Declaration}

The study does not involve any ethical subjects.

\section{Conflict of Interest}

There is no conflict of interest.

\section{Authors Contribution}

All authors contributed equally to this work.

\section{References}

1. Ambrose, S. J., Harmer, C. J., \& Hall, R. M. (2018). Evolution and typing of IncC plasmids contributing to antibiotic resistance in Gram-negative bacteria. Plasmid, 99(June), 40-55. https://doi.org/10.1016/j.plasmid.2018.08.001 
2. Bai, F., Li, X., Niu, B., Zhang, Z., Malakar, P. K., Liu, H., Pan, Y., \& Zhao, Y. (2018). A mcr-1-Carrying Conjugative IncX4 Plasmid in Colistin-Resistant Escherichia coli ST278 Strain Isolated From Dairy Cow Feces in Shanghai, China. Frontiers in Microbiology, 9(NOV), 1-9. https://doi.org/10.3389/fmicb.2018.02833.

3. Bagley, S. T. (1985). Habitat association of Klebsiella species. Infection Control \& Hospital Epidemiology, 6(2), 52-58. https://doi.org/10.1017/S0195941700062603.

4. Bertelli, C., Tilley, K. E., \& Brinkman, F. S. L. (2019). Microbial genomic island discovery, visualization and analysis. Briefings in Bioinformatics, 20(5), 1685-1698. https://doi.org/10.1093/bib/bby042

5. Bi, D., Zheng, J., Li, J. J., Sheng, Z. K., Zhu, X., Ou, H. Y., Li, Q., \& Wei, Q. (2018). In silico typing and comparative genomic analysis of incfiik plasmids and insights into the evolution of replicons, plasmid backbones, and resistance determinant profiles. Antimicrobial Agents and Chemotherapy, 62(10). https://doi.org/10.1128/AAC.00764-18.

6. Bradford, P. A. (2001). Extended-spectrum $\beta$-lactamases in the 21 st century: Characterization, epidemiology, and detection of this important resistance threat. Clinical Microbiology Reviews, 14(4), 933-951. https://doi.org/10.1128/CMR.14.4.933-951.2001

7. Brisse, S., Passet, V., Haugaard, A. B., Babosan, A., Kassis-Chikhani, N., Struve, C., \& Decré, D. (2013). wzi gene sequencing, a rapid method for determination of capsular type for Klebsiella strains. Journal of clinical microbiology, 51(12), 4073-4078. https://doi.org/10.1128/JCM.01924-13

8. Carattoli, A., Zankari, E., Garciá-Fernández, A., Larsen, M. V., Lund, O., Villa, L., Aarestrup, F. M., \& Hasman, H. (2014). In Silico detection and typing of plasmids using plasmidfinder and plasmid multilocus sequence typing. Antimicrobial Agents and Chemotherapy, 58(7), 3895-3903. https://doi.org/10.1128/AAC.02412-14

9. Chen, Liang, Chavda, K. D., Melano, R. G., Hong, T., Rojtman, A. D., Jacobs, M. R., Bonomo, R. A., \& Kreiswirth, B. N. (2014). Molecular survey of the dissemination of two blaKPC-harboring IncFIA plasmids in New Jersey and New York Hospitals. Antimicrobial Agents and Chemotherapy, 58(4), 2289-2294. https://doi.org/10.1128/AAC.02749-13

10. Chen, Linxiang, Cai, Y., Zhou, G., Shi, X., Su, J., Chen, G., \& Lin, K. (2014). Rapid Sanger sequencing of the $16 \mathrm{~S}$ rRNA gene for identification of some common pathogens. PLoS ONE, 9(2), 1-10. https://doi.org/10.1371/journal.pone.0088886

11. Chou, H. C., Lee, C. Z., Ma, L. C., Fang, C. T., Chang, S. C., \& Wang, J. T. (2004). Isolation of a chromosomal region of Klebsiella pneumoniae associated with allantoin metabolism and liver infection. Infection and Immunity, 72(7), 3783-3792. https://doi.org/10.1128/IAI.72.7.37833792.2004

12. Cortés, G., Borrell, N., De Astorza, B., Gómez, C., Sauleda, J., \& Albertí, S. (2002). Molecular analysis of the contribution of the capsular polysaccharide and the lipopolysaccharide 0 side chain to the virulence of Klebsiella pneumoniae in a murine model of pneumonia. Infection and Immunity, 70(5), 2583-2590. https://doi.org/10.1128/IAI.70.5.2583-2590.2002 
13. Dong, N., Liu, L., Zhang, R., Chen, K., Xie, M., Chan, E. W. C., \& Chen, S. (2019). An IncR plasmid harbored by a hypervirulent carbapenem-resistant klebsiella pneumoniae strain possesses five tandem repeats of the blaKPC-2::NTEKPC-Id Fragment. Antimicrobial Agents and Chemotherapy, 63(3), 1-12. https://doi.org/10.1128/AAC.01775-18

14. Effah, C. Y., Sun, T., Liu, S., \& Wu, Y. (2020). Klebsiella pneumoniae: An increasing threat to public health. Annals of Clinical Microbiology and Antimicrobials, 19(1), 1-9. https://doi.org/10.1186/s12941-019-0343-8

15. Feng, J., Yin, Z., Zhao, Q., Zhao, Y., Zhang, D., Jiang, X., Wu, W., Chen, W., Wang, H., Song, Y., Tong, Y., Wang, J., Li, Y., \& Zhou, D. (2017). Genomic characterization of novel IncFll-type multidrug resistant plasmids p0716-KPC and p12181-KPC from Klebsiella pneumonia. Scientific Reports, 7(1), 1-7. https://doi.org/10.1038/s41598-017-06283-z

16. Flokas, M. E., Karanika, S., Alevizakos, M., \& Mylonakis, E. (2017). Prevalence of ESBL-producing Enterobacteriaceae in pediatric bloodstream infections: A systematic review and meta-analysis. PLOS ONE, 12(1), 1-13. https://doi.org/10.1371/journal.pone.0171216

17. Hendriksen, R. S., Bortolaia, V., Tate, H., Tyson, G. H., Aarestrup, F. M., \& McDermott, P. F. (2019). Using Genomics to Track Global Antimicrobial Resistance. Frontiers in Public Health, 7(September). https://doi.org/10.3389/fpubh.2019.00242

18. Highsmith, A. K., \& Jarvis, W. R. (1985). Klebsiella Selected pneumoniae: Pathogenicity. Infection Control, 6(2), 75-77.

19. Jousset, A. B., Rosinski-Chupin, I., Takissian, J., Glaser, P., Bonnin, R. A., \& Naas, T. (2018). Transcriptional Landscape of a blaKPC-2 Plasmid and Response to Imipenem Exposure in Escherichia coli TOP10. Frontiers in Microbiology, 9(December), 1-19. https://doi.org/10.3389/fmicb.2018.02929

20. Kumar, V., Sun, P., Vamathevan, J., Li, Y., Ingraham, K., Palmer, L., ... \& Brown, J. R. (2011). Comparative genomics of Klebsiella pneumoniae strains with different antibiotic resistance profiles. Antimicrobial agents and chemotherapy, 55(9), 4267-4276. https://doi.org/10.1128/AAC.00052-11

21. Kuralayanapalya, S. P., Patil, S. S., Hamsapriya, S., Shinduja, R., Roy, P., \& Amachawadi, R. G. (2019). Prevalence of extended-spectrum beta-lactamase producing bacteria from animal origin: A systematic review and meta-analysis report from India. PLOS ONE, 14(9), 1-15. https://doi.org/10.1371/journal.pone.0221771

22. Kwon, T., Jung, Y. H., Lee, S., Yun, M. R., Kim, W., \& Kim, D. W. (2016). Comparative genomic analysis of Klebsiella pneumoniae subsp. pneumoniae KP617 and PittNDM01, NUHL24835, and ATCC BAA2146 reveals unique evolutionary history of this strain. Gut Pathogens, 8(1), 1-16. https://doi.org/10.1186/s13099-016-0117-1

23. Lee, C. R., Lee, J. H., Park, K. S., Jeon, J. H., Kim, Y. B., Cha, C. J., Jeong, B. C., \& Lee, S. H. (2017). Antimicrobial resistance of hypervirulent Klebsiella pneumoniae: Epidemiology, hypervirulenceassociated determinants, and resistance mechanisms. Frontiers in Cellular and Infection Microbiology, 7(NOV). https://doi.org/10.3389/fcimb.2017.00483 
24. Li, X., Ma, W., Qin, Q., Liu, S., Ye, L., Yang, J., \& Li, B. (2019). Nosocomial spread of OXA-232-producing Klebsiella pneumoniae ST15 in a teaching hospital, Shanghai, China. BMC Microbiology, 19(1), 1-6. https://doi.org/10.1186/s12866-019-1609-1

1. Lin, W. H., Tseng, C. C., Wu, A. B., Yang, D. C., Cheng, S. W., Wang, M. C., \& Wu, J. J. (2015). Clinical and microbiological characteristics of peritoneal dialysis-related peritonitis caused by Klebsiella pneumoniae in southern Taiwan. Journal of Microbiology, Immunology and Infection, 48(3), 276283. https://doi.org/10.1016/j.jmii.2013.10.002

2. Lin, D., Xie, M., Li, R., Chen, K., Chan, E. W. C., \& Chen, S. (2017). IncFIl conjugative plasmid-mediated transmission of bla NDM-1 elements among animal-borne Escherichia coli strains. Antimicrobial agents and chemotherapy, 61(1), e02285-16. https://doi.org/10.1128/AAC.02285-16.

3. Maclean, A. K. W., \& Hanson, N. D. (2021). Draft Genome Sequences of the Clinical Isolates Kp 23 and KPM 20. Microbiology Resource Announcements, 10(12), 20-21. https://doi.org/10.1128/mra.00119-21

28. Martin, R. M., \& Bachman, M. A. (2018). Colonization, infection, and the accessory genome of Klebsiella pneumoniae. Frontiers in Cellular and Infection Microbiology, 8(JAN), 1-15. https://doi.org/10.3389/fcimb.2018.00004

29. McArthur, A. G., Waglechner, N., Nizam, F., Yan, A., Azad, M. A., Baylay, A. J., Bhullar, K., Canova, M. J., De Pascale, G., Ejim, L., Kalan, L., King, A. M., Koteva, K., Morar, M., Mulvey, M. R., O'Brien, J. S., Pawlowski, A. C., Piddock, L. J. V., Spanogiannopoulos, P., ... Wright, G. D. (2013). The comprehensive antibiotic resistance database. Antimicrobial Agents and Chemotherapy, 57(7), 3348-3357. https://doi.org/10.1128/AAC.00419-13

30. Newire, E., Aydin, A., Juma, S., Enne, V. I., \& Roberts, A. P. (2020). Identification of a Type IV-A CRISPRCas System Located Exclusively on IncHI1B/IncFIB Plasmids in Enterobacteriaceae. Frontiers in Microbiology, 11(August), 1-11. https://doi.org/10.3389/fmicb.2020.01937

31. Ni, R. T., Onishi, M., Mizusawa, M., Kitagawa, R., Kishino, T., Matsubara, F., Tsuchiya, T., Kuroda, T., \& Ogawa, W. (2020). The role of RND-type efflux pumps in multidrug-resistant mutants of Klebsiella pneumoniae. Scientific Reports, 10(1), 1-10. https://doi.org/10.1038/s41598-020-67820-x

32. Nicolás, M. F., Ramos, P. I. P., de Carvalho, F. M., Camargo, D. R. A., Alves, C. de F. M., de Morais, G. L., Almeida, L. G. P., Souza, R. C., Ciapina, L. P., Vicente, A. C. P., Coimbra, R. S., \& de Vasconcelos, A. T. R. (2018). Comparative genomic analysis of a clinical isolate of Klebsiella quasipneumoniae subsp. similipneumoniae, a KP -2 and OKP-B-6 beta-lactamases producer harboring two drug-resistance plasmids from Southeast Brazil. Frontiers in Microbiology, 9(FEB). https://doi.org/10.3389/fmicb.2018.00220

33. Oladeinde, A., Cook, K., Orlek, A., Zock, G., Herrington, K., Cox, N., Lawrence, J. P., \& Hall, C. (2018). Hotspot mutations and ColE1 plasmids contribute to the fitness of Salmonella Heidelberg in poultry litter. In PLOS ONE (Vol. 13, Issue 8). https://doi.org/10.1371/journal.pone.0202286 
34. Paczosa, M. K., \& Mecsas, J. (2016). Klebsiella pneumoniae: ir a la ofensiva con una defensa fuerte. Microbiology and Molecular Biology Reviews, 80(3), 629-661.

https://doi.org/10.1128/MMBR.00078-15.Address

35. Pál, T., \& Sonnevend, Á. (2019). Epidemic IncX3 plasmids spreading carbapenemase genes in the United Arab Emirates and worldwide. 1729-1742.

36. Parkinson, H., Kapushesky, M., Shojatalab, M., Abeygunawardena, N., Coulson, R., Farne, A., Holloway, E., Kolesnykov, N., Lilja, P., Lukk, M., Mani, R., Rayner, T., Sharma, A., William, E., Sarkans, U., \& Brazma, A. (2007). ArrayExpress - A public database of microarray experiments and gene expression profiles. Nucleic Acids Research, 35(SUPPL. 1), 747-750. https://doi.org/10.1093/nar/gkl995

37. Parrott, A. M., Shi, J., Aaron, J., Green, D. A., Whittier, S., \& Wu, F. (2021). Detection of multiple hypervirulent Klebsiella pneumoniae strains in a New York City hospital through screening of virulence genes. Clinical Microbiology and Infection, 27(4), 583-589.

https://doi.org/10.1016/j.cmi.2020.05.012

38. Perdigão, J., Caneiras, C., Elias, R., Modesto, A., Spadar, A., Phelan, J., Campino, S., Clark, T. G., Costa, E., Saavedra, M. J., \& Duarte, A. (2020). Genomic epidemiology of carbapenemase producing klebsiella pneumoniae strains at a northern portuguese hospital enables the detection of a misidentified klebsiella variicola kpc-3 producing strain. Microorganisms, 8(12), 1-18. https://doi.org/10.3390/microorganisms8121986

39. Peterson, E., \& Kaur, P. (2018). Antibiotic resistance mechanisms in bacteria: Relationships between resistance determinants of antibiotic producers, environmental bacteria, and clinical pathogens. Frontiers in Microbiology, 9(NOV), 1-21. https://doi.org/10.3389/fmicb.2018.02928

40. R. PODSCHUN*, AND, \& U. ULLMANN. (1998). Klebsiella spp. as Nosocomial Pathogens. 11(4), 589603. https://www-ncbi-nlm-nih-gov.proxy-ub.rug.nl/pmc/articles/PMC88898/pdf/cm000589.pdf

41. Rajkumari, J., Choudhury, Y., Bhattacharjee, K., \& Pandey, P. (2021). Rhizodegradation of Pyrene by a Non-pathogenic Klebsiella pneumoniae Isolate Applied With Tagetes erecta L. and Changes in the Rhizobacterial Community. Frontiers in Microbiology, 12(February).

https://doi.org/10.3389/fmicb.2021.593023

42. Roemhild, R., \& Schulenburg, H. (2019). Evolutionary ecology meets the antibiotic crisis. Evolution, Medicine and Public Health, 2019(1), 37-45. https://doi.org/10.1093/emph/eoz008

1. Rozwandowicz, M., Brouwer, M. S. M., Fischer, J., Wagenaar, J. A., Gonzalez-Zorn, B., Guerra, B., Mevius, D. J., \& Hordijk, J. (2018). Plasmids carrying antimicrobial resistance genes in Enterobacteriaceae. Journal of Antimicrobial Chemotherapy, 73(5), 1121-1137. https://doi.org/10.1093/jac/dkx488

2. Russo, T. A., \& Marr, C. M. (2019). Hypervirulent Klebsiella pneumoniae. Clinical microbiology reviews, 32(3), e00001-19. https://doi.org/10.1128/CMR.00001-19.

3. Sartelli, M., Weber, D. G., Ruppé, E., Bassetti, M., Wright, B. J., Ansaloni, L., Catena, F., Coccolini, F., AbuZidan, F. M., Coimbra, R., Moore, E. E., Moore, F. A., Maier, R. V., De Waele, J. J., Kirkpatrick, A. W., Griffiths, E. A., Eckmann, C., Brink, A. J., Mazuski, J. E., ... Viale, P. (2016). Antimicrobials: A global 
alliance for optimizing their rational use in intra-abdominal infections (AGORA). World Journal of Emergency Surgery, 11(1), 1-32. https://doi.org/10.1186/s13017-016-0089-y

46. Serban, D., Popa Cherecheanu, A., Dascalu, A. M., Socea, B., Vancea, G., Stana, D., Smarandache, G. C., Sabau, A. D., \& Costea, D. O. (2021). Hypervirulent klebsiella pneumoniae endogenous endophthalmitis-a global emerging disease. Life, 11(7), 1-16. https://doi.org/10.3390/life11070676

47. Shankar, C., Muthuirulandi Sethuvel, D. P., Neeravi, A. R., Venkatesan, M., Devanga Ragupathi, N. K., Anandan, S., \& Veeraraghavan, B. (2020). Identification of plasmids by PCR based replicon typing in bacteremic Klebsiella pneumoniae. Microbial Pathogenesis, 148(June 2019), 104429. https://doi.org/10.1016/j.micpath.2020.104429

48. Shon, A. S., Bajwa, R. P. S., \& Russo, T. A. (2013). Hypervirulent (hypermucoviscous) Klebsiella Pneumoniae: A new and dangerous breed. Virulence, 4(2), 107-118. https://doi.org/10.4161/viru.22718

49. Souza, R. C. de, Dabul, A. N. G., Boralli, C. M. dos S., Zuvanov, L., \& Camargo, I. L. B. da C. (2019). Dissemination of blaKPC-2 in an NTEKPC by an IncX5 plasmid. Plasmid, 106(October), 1-7. https://doi.org/10.1016/j.plasmid.2019.102446

50. Tokajian, S., Eisen, J. A., Jospin, G., Farra, A., \& Coil, D. A. (2015). Whole genome sequencing of extended-spectrum $\beta$-lactamase producing Klebsiella pneumoniae isolated from a patient in Lebanon. Frontiers in Cellular and Infection Microbiology, 5(APR), 1-7. https://doi.org/10.3389/fcimb.2015.00032

51. Uruén, C., Chopo-Escuin, G., Tommassen, J., Mainar-Jaime, R. C., \& Arenas, J. (2021). Biofilms as promoters of bacterial antibiotic resistance and tolerance. Antibiotics, 10(1), 1-36. https://doi.org/10.3390/antibiotics10010003

52. van Duin, D., \& Paterson, D. L. (2016). Multidrug-Resistant Bacteria in the Community: Trends and Lessons Learned. Infectious Disease Clinics of North America, 30(2), 377-390. https://doi.org/10.1016/j.idc.2016.02.004

53. Wattam, A. R., Brettin, T., Davis, J. J., Gerdes, S., Kenyon, R., Machi, D., Mao, C., Olson, R., Overbeek, R., Pusch, G. D., Shukla, M. P., Stevens, R., Vonstein, V., Warren, A., Xia, F., \& Yoo, H. (2018). Assembly, annotation, and comparative genomics in PATRIC, the all bacterial bioinformatics resource center. Methods in Molecular Biology, 1704, 79-101. https://doi.org/10.1007/978-1-4939-7463-4_4

54. Wyres, K. L., \& Holt, K. E. (2018). Klebsiella pneumoniae as a key trafficker of drug resistance genes from environmental to clinically important bacteria. Current Opinion in Microbiology, 45, 131-139. https://doi.org/10.1016/j.mib.2018.04.004

1. Wyres, K. L., Nguyen, T. N. T., Lam, M. M. C., Judd, L. M., van Vinh Chau, N., Dance, D. A. B., Ip, M., Karkey, A., Ling, C. L., Miliya, T., Newton, P. N., Nguyen, L., Sengduangphachanh, A., Turner, P., Veeraraghavan, B., Vinh, P. V., Vongsouvath, M., Thomson, N. R., Baker, S., \& Holt, K. E. (2019). 
Genomic surveillance for hypervirulence and multi-drug resistance in invasive Klebsiella pneumoniae from south and southeast Asia. BioRxiv, 1-16. https://doi.org/10.1101/557785

2. Wysocka, M., Zamudio, R., Oggioni, M. R., Gołębiewska, J., Bronk, M., \& Krawczyk, B. (2021). Genetic Background and Antibiotic Resistance Profiles of K. pneumoniae NDM-1 Strains Isolated from UTI, $A B U$, and the GI Tract, from One Hospital in Poland, in Relation to Strains Nationally and Worldwide. Genes, 12(8), 1285. https://doi.org/10.3390/genes12081285.

3. Xie, Y., Tian, L., Li, G., Qu, H., Sun, J., Liang, W., Li, X., Wang, X., Deng, Z., Liu, J., \& Ou, H. Y. (2018). Emergence of the third-generation cephalosporin-resistant hypervirulent klebsiella pneumoniae due to the acquisition of a self-transferable blaDHA-1-carrying plasmid by an ST23 strain. Virulence, 9(1), 838-844. https://doi.org/10.1080/21505594.2018.1456229

58. Yang, L., Lin, Y., Lu, L., Xue, M., Ma, H., Guo, X., Wang, K., Li, P., Du, X., Qi, K., Li, P., \& Song, H. (2020). Coexistence of Two blaNDM- 5 Genes Carried on IncX3 and IncFII Plasmids in an Escherichia coli Isolate Revealed by Illumina and Nanopore Sequencing. Frontiers in Microbiology, 11(February), 1-7. https://doi.org/10.3389/fmicb.2020.00195

59. Yu, W. L., Ko, W. C., Cheng, K. C., Lee, C. C., Lai, C. C., \& Chuang, Y. C. (2008). Comparison of prevalence of virulence factors for Klebsiella pneumoniae liver abscesses between isolates with capsular K1/K2 and non-K1/K2 serotypes. Diagnostic Microbiology and Infectious Disease, 62(1), 16. https://doi.org/10.1016/j.diagmicrobio.2008.04.007

60. Zhang, C., Feng, Y., Liu, F., Jiang, H., Qu, Z., Lei, M., Wang, J., Zhang, B., Hu, Y., Ding, J., \& Zhu, B. (2017). A phage-like IncY plasmid carrying the mcr-1 gene in Escherichia coli from a pig farm in China. Antimicrobial Agents and Chemotherapy, 61(3), 1-12. https://doi.org/10.1128/AAC.02035-16

61. Zhao, J., Liu, C., Liu, Y., Zhang, Y., Xiong, Z., Fan, Y., Zou, X., Lu, B., \& Cao, B. (2020). Genomic characteristics of clinically important ST11 Klebsiella pneumoniae strains worldwide. Journal of Global Antimicrobial Resistance, 22, 519-526. https://doi.org/10.1016/j.jgar.2020.03.023

62. Zhu, J., Wang, T., Chen, L., \& Du, H. (2021). Virulence Factors in Hypervirulent Klebsiella pneumoniae. Frontiers in Microbiology, 12(April), 1-14. https://doi.org/10.3389/fmicb.2021.642484

\section{Tables}

Table 1: The replicon type, family and function. 


\begin{tabular}{|c|c|c|c|c|}
\hline Plasmid & Family & $\begin{array}{l}\text { Antibiotic } \\
\text { resistant Genes }\end{array}$ & $\begin{array}{l}\text { Functions of The } \\
\text { Plasmid }\end{array}$ & References \\
\hline pKpQIL-IT & IncFIB(pQil) & $\begin{array}{l}\text { Aminoglycoside } \\
\text { resistant gene }\end{array}$ & $\begin{array}{l}\text { Carrier, transfer and } \\
\text { MDR function }\end{array}$ & $\begin{array}{l}\text { (Jousset et al., } \\
\text { 2018) }\end{array}$ \\
\hline pK245 & IncR & blaCTX-M-15 & $\begin{array}{l}\text { Carbapenenem } \\
\text { resistance gene }\end{array}$ & $\begin{array}{l}\text { (Dong et al., } \\
\text { 2019) }\end{array}$ \\
\hline pK2044 & repB & tetC, tetD & $\begin{array}{l}\text { conjugal transfer and } \\
\text { maintenance }\end{array}$ & $\begin{array}{l}\text { (Feng et al., } \\
\text { 2017) }\end{array}$ \\
\hline pVCM01 & IncFII & $\begin{array}{l}\text { blaCTX-M-15, } \\
\text { blaNDM-5, } \\
\text { blaTEM-1 and } \\
\text { blaOXA-1 }\end{array}$ & $\begin{array}{l}\text { conjugal transfer and } \\
\text { maintenance }\end{array}$ & $\begin{array}{l}\text { (Feng et al., } \\
\text { 2017) }\end{array}$ \\
\hline pKPX-1 & IncFII(pKPX1) & $\begin{array}{l}\text { blaNDM-1, } \\
\text { blaCTX-M-15, } \\
\text { blaTEM-1, } \\
\text { blaOXA-1 }\end{array}$ & $\begin{array}{l}\text { conjugal transfer and } \\
\text { maintenance }\end{array}$ & $\begin{array}{l}\text { (Wysocka et } \\
\text { al., 2021) }\end{array}$ \\
\hline pKPN-IT & $\operatorname{lncFIB}(\mathrm{K})$ & & $\begin{array}{l}\text { conjugal transfer and } \\
\text { maintenance }\end{array}$ & $\begin{array}{l}\text { (Feng et al., } \\
\text { 2017) }\end{array}$ \\
\hline pNDM-MAR & $\begin{array}{l}\text { IncHI1B(pNDM- } \\
\text { MAR) }\end{array}$ & $\begin{array}{l}\text { blaCTX-M-15, } \\
\text { blaNDM, qnrB1 }\end{array}$ & $\begin{array}{l}\text { Limiting plasmid } \\
\text { dissemination among } \\
\text { potential host }\end{array}$ & $\begin{array}{l}\text { (Newire et al., } \\
2020 \text { ) }\end{array}$ \\
\hline plncX-SHV & IncX3 & blaNDM-5 & $\begin{array}{l}\text { Carbapenemase } \\
\text { resistance genes }\end{array}$ & $\begin{array}{l}\text { (Pál \& } \\
\text { Sonnevend, } \\
\text { 2019) }\end{array}$ \\
\hline pNDM-MAR & $\begin{array}{l}\text { IncFI1B(pNDM- } \\
\text { MAR) }\end{array}$ & $N D M-1$ & $\begin{array}{l}\text { Limiting plasmid } \\
\text { dissemination among } \\
\text { potential }\end{array}$ & $\begin{array}{l}\text { (Newire et al., } \\
2020 \text { ) }\end{array}$ \\
\hline рT5282-СТXM & IncX5 & blaKPC-5 & Dissemination & $\begin{array}{l}\text { (Souza et al., } \\
\text { 2019) }\end{array}$ \\
\hline pNDM-KN & IncC & $\begin{array}{l}\text { blaCMY, blaNDM- } \\
1\end{array}$ & $\begin{array}{l}\text { Broad host range } \\
\text { capable of carrying, } \\
\text { transfer and MDR } \\
\text { function }\end{array}$ & $\begin{array}{l}\text { (Ambrose et } \\
\text { al., 2018) }\end{array}$ \\
\hline pKPN3 & $\operatorname{lncFII}(\mathrm{K})$ & blaKPC-2 & $\begin{array}{l}\text { Acquisition and } \\
\text { dissemination of } \\
\text { MDR }\end{array}$ & $\begin{array}{l}\text { (Bi et al., } \\
2018)\end{array}$ \\
\hline pCROD2 & IncX4 & $m c r-1$ & $\begin{array}{l}\text { MCR-1 carrying } \\
\text { conjugative plasmid }\end{array}$ & $\begin{array}{l}\text { (Bai et al., } \\
2018 \text { ) }\end{array}$ \\
\hline
\end{tabular}




\begin{tabular}{|c|c|c|c|c|}
\hline P1 RepA (repA) & IncY & $m c r-1$ & Phage- like plasmids & $\begin{array}{l}\text { (Zhang et al., } \\
\text { 2017) }\end{array}$ \\
\hline pHN7A8 & IncFII(pHN7A8) & blaNDM-1 & $\begin{array}{l}\text { Acquisition and } \\
\text { dissemination of } \\
\text { MDR }\end{array}$ & $\begin{array}{l}\text { (Lin et al., } \\
\text { 2017) }\end{array}$ \\
\hline pMET-1 FC1 & IncFII(pMET) & blaOXA-48 & $\begin{array}{l}\text { Acquisition and } \\
\text { dissemination of } \\
\text { MDR }\end{array}$ & $\begin{array}{l}\text { (Perdigão et } \\
\text { al., 2020) }\end{array}$ \\
\hline pCAV1099-114 & $\begin{array}{l}\operatorname{IncFIB}(\mathrm{K}) \\
\text { (pCAV1099- } \\
114 \text { ) }\end{array}$ & $\begin{array}{l}\text { blasHV-56, fosA, } \\
\text { oqxA, and oqxB }\end{array}$ & $\begin{array}{l}\text { conjugal transfer and } \\
\text { maintenance }\end{array}$ & $\begin{array}{l}\text { (Maclean \& } \\
\text { Hanson, } \\
\text { 2021) }\end{array}$ \\
\hline pKPHS1 & IncFIB(pKPHS1) & $\begin{array}{l}K P C, O X A-48 \text { and } \\
N D M-1\end{array}$ & $\begin{array}{l}\text { conjugal transfer and } \\
\text { maintenance }\end{array}$ & $\begin{array}{l}\text { (Wyres \& Holt, } \\
\text { 2018) }\end{array}$ \\
\hline pBK30683 & FIA(pBK30683) & blaKPC-3 & $\begin{array}{l}\text { Transfer and MDR } \\
\text { function }\end{array}$ & $\begin{array}{l}\text { (Liang Chen et } \\
\text { al., 2014) }\end{array}$ \\
\hline FDAARGOS_440 & Col440I & $\begin{array}{l}\text { blaCTX-M-15, } \\
\text { blaOXA-1, tet(B), } \\
\text { tet(D), } \operatorname{aac}\left(6^{\prime}\right)-1 b- \\
\text { cr }\end{array}$ & $\begin{array}{l}\text { bla-KPC bearing } \\
\text { plasmids }\end{array}$ & $\begin{array}{l}\text { (Yang et al., } \\
2020)\end{array}$ \\
\hline pKP3-A & ColKP3 & $\begin{array}{l}\text { bla- OXA-232, } \\
\text { blaOXA-181 }\end{array}$ & $\begin{array}{l}\text { Carries carbapenem } \\
\text { resistance genes } \\
\text { (oxa) }\end{array}$ & $\begin{array}{l}\text { (Li et al., } \\
\text { 2019; Shankar } \\
\text { et al., 2020) }\end{array}$ \\
\hline pBS512_2 & Col(BS512) & $\begin{array}{l}\text { blaOXA-48, } \\
\text { blaNDM- } \\
1 \text { and blaCTX-M-3 }\end{array}$ & $\begin{array}{l}\text { Carbapenenem } \\
\text { resistance gene }\end{array}$ & $\begin{array}{l}\text { (Tokajian et } \\
\text { al., 2015) }\end{array}$ \\
\hline pVCM01 & ColpVC & blaOXA-181 & $\begin{array}{l}\text { Hot spot bearing } \\
\text { plasmid (fitness) }\end{array}$ & $\begin{array}{l}\text { (Oladeinde et } \\
\text { al., 2018) }\end{array}$ \\
\hline
\end{tabular}

\section{Figures}


Tree scale: 0.1

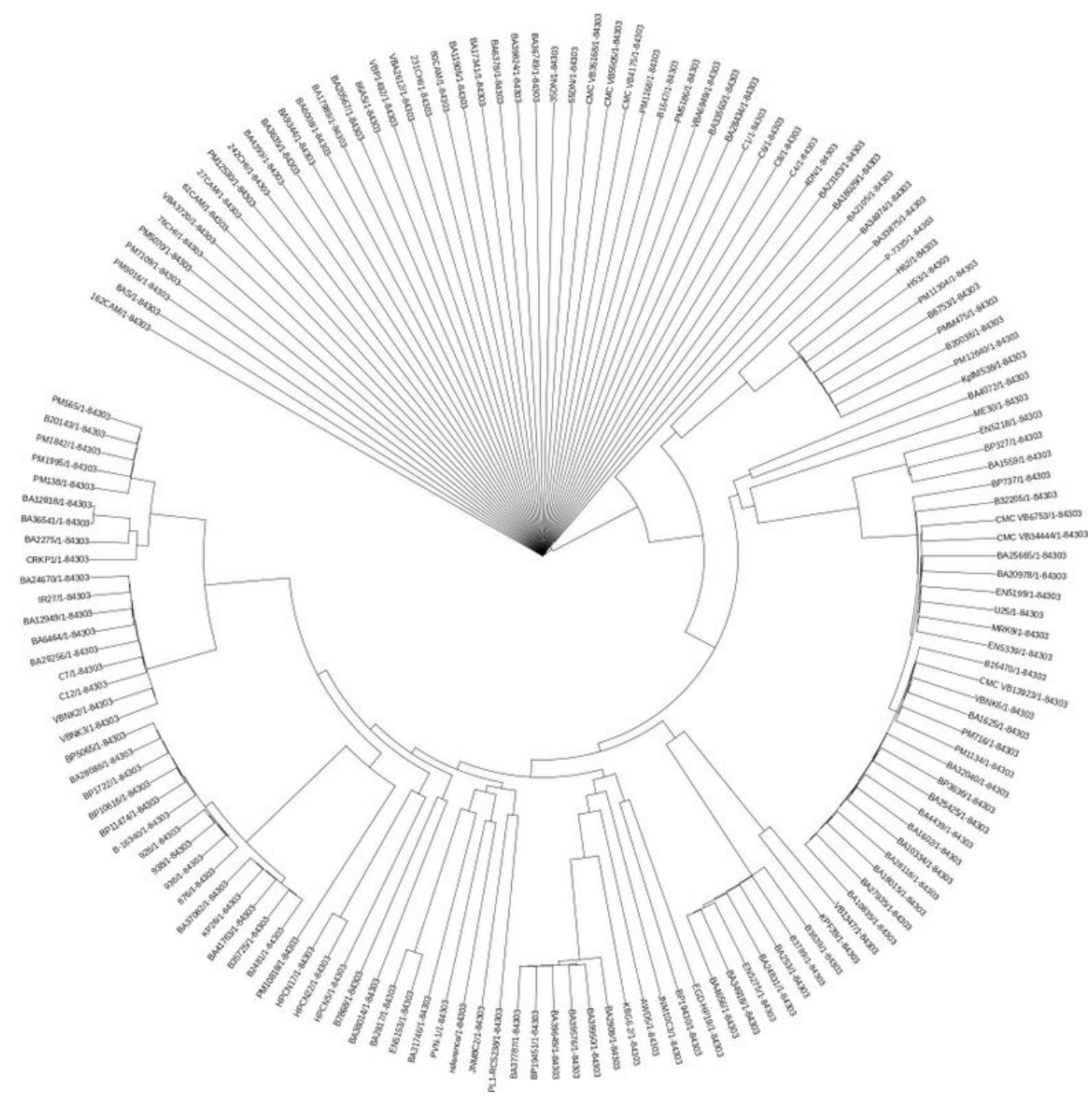

\section{Figure 1}

Phylogenetic tree based on SNP SNP phylogeny was constructed by the neighbor joining method with MegaX. 1,000 bootstrap replicates were calculated to assess robustness. The midpoint of the phylogenetic tree was divided into 2 major clades and further delineated into many clusters of $\mathrm{K}$. pneumoniae. The environmental strains were grouped in clade 1, whereas ME30 the endophyte isolate aligned in clade 2 . 


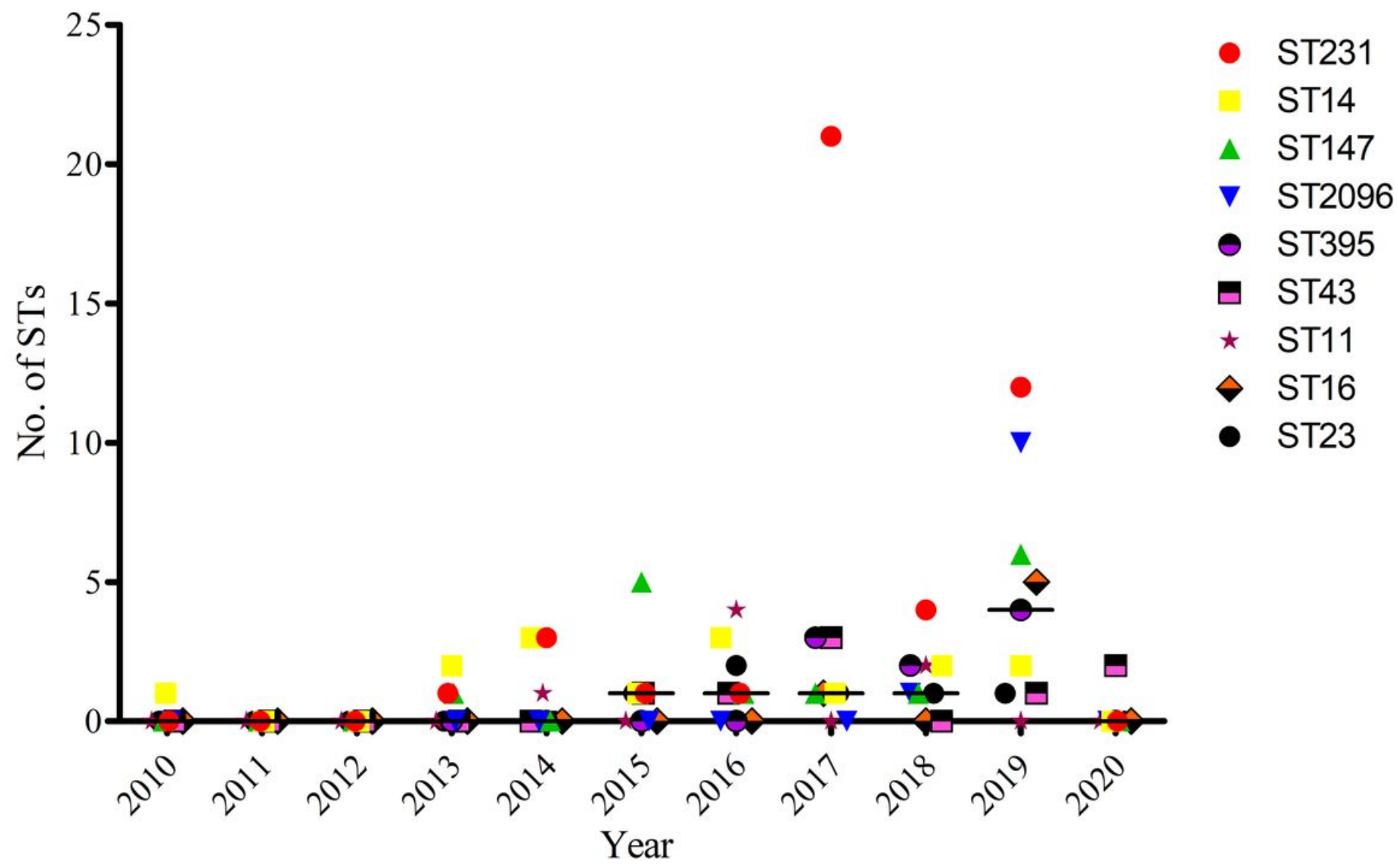

Figure 2

Year-wise ST distribution The Scatter plot represents the distribution of STs across 2010-2020. ST231, ST147, ST2096 are displayed with increasing trends during 2013, 2015 and 2018. The points represent the STs representing the abundance from high to less. The line denotes the median points. 


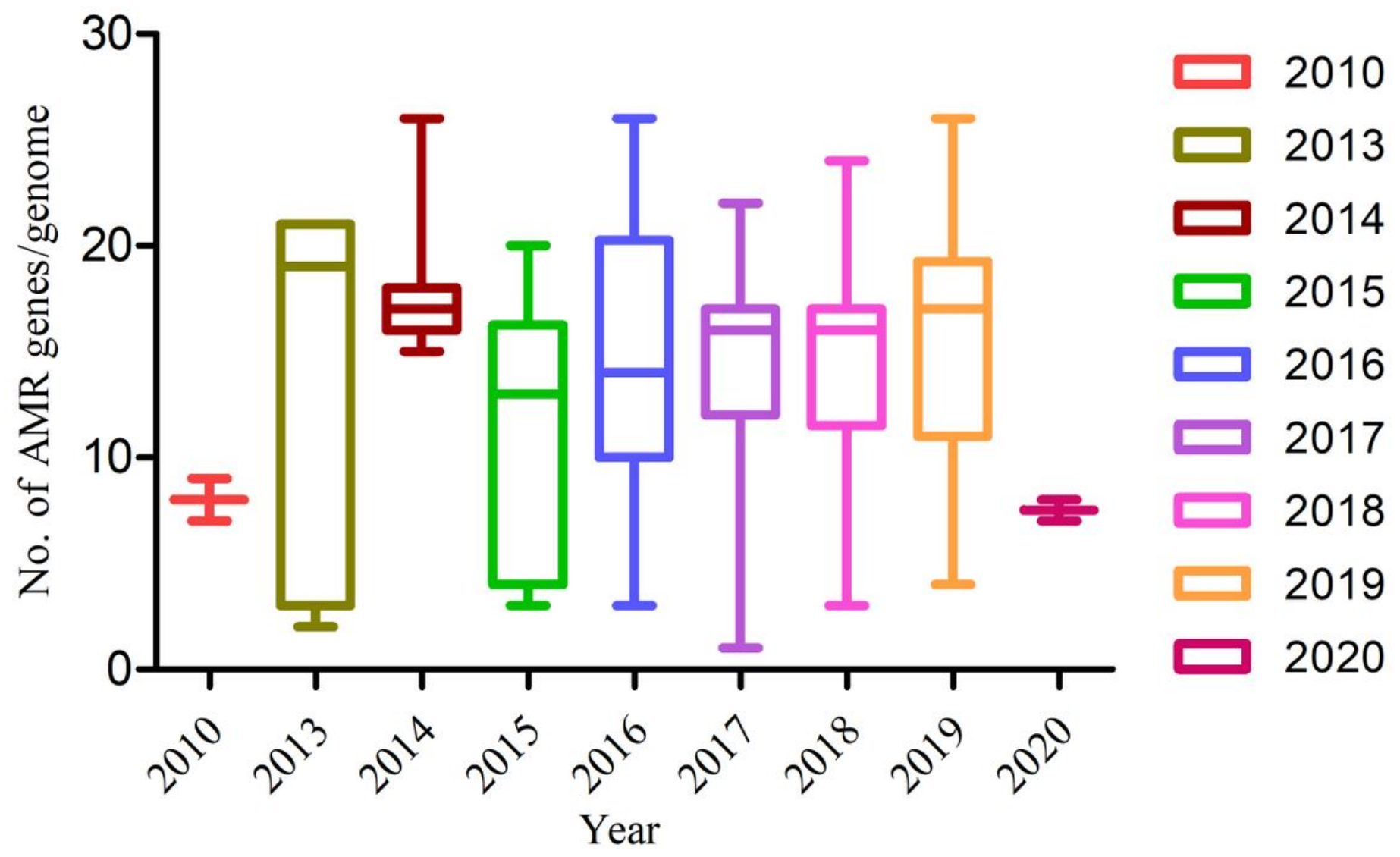

Figure 3

Distribution of AMR genes in K. pneumoniae isolates during 2010-2020 The Box plot represents the presence of one AMR and to the maximum of 26 AMR genes. The average median distribution of 15 AMR genes/genomes were noticed from 2013-2017. The bold horizontal lines represent the median. The whisker represents the upper and lower adjacent values. 


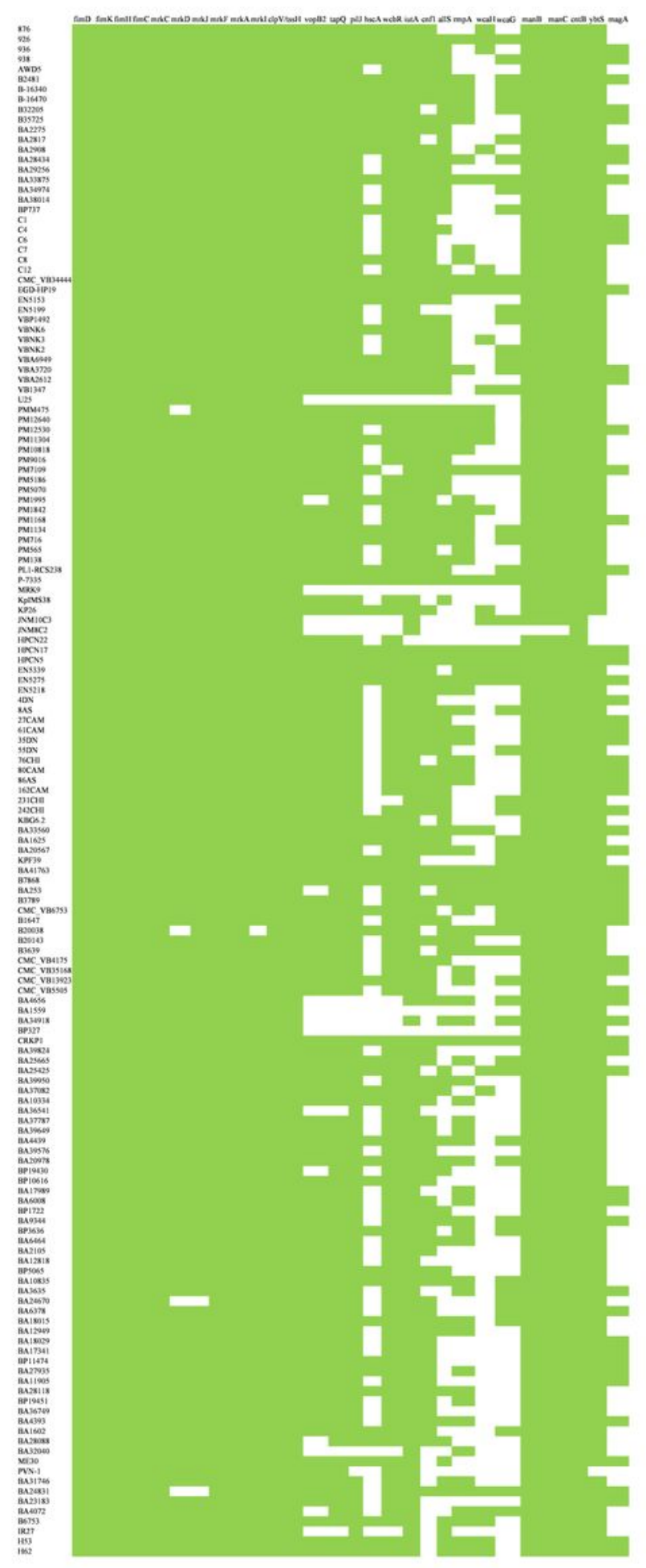

Figure 4

Virulome of K. pneumoniae The virulence genes $(n=27)$ in K. pneumoniae are screened using VFDB. The colour indicates the presence of virulence genes. 


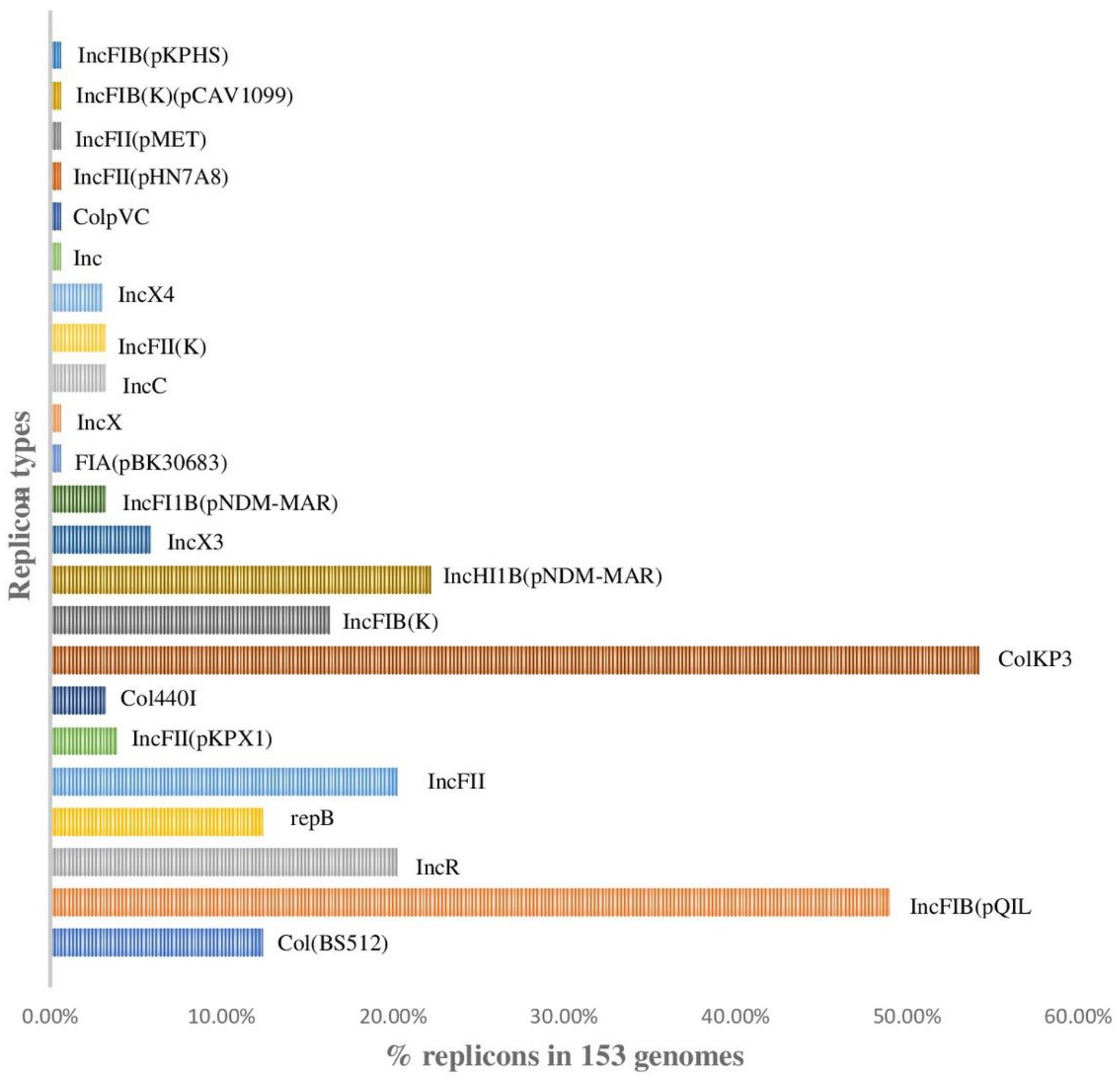

\section{Figure 5}

Prevalence of replicon types among the study strains The bar graph corresponds to the percentage distribution of replicon types among 153 genomes. 


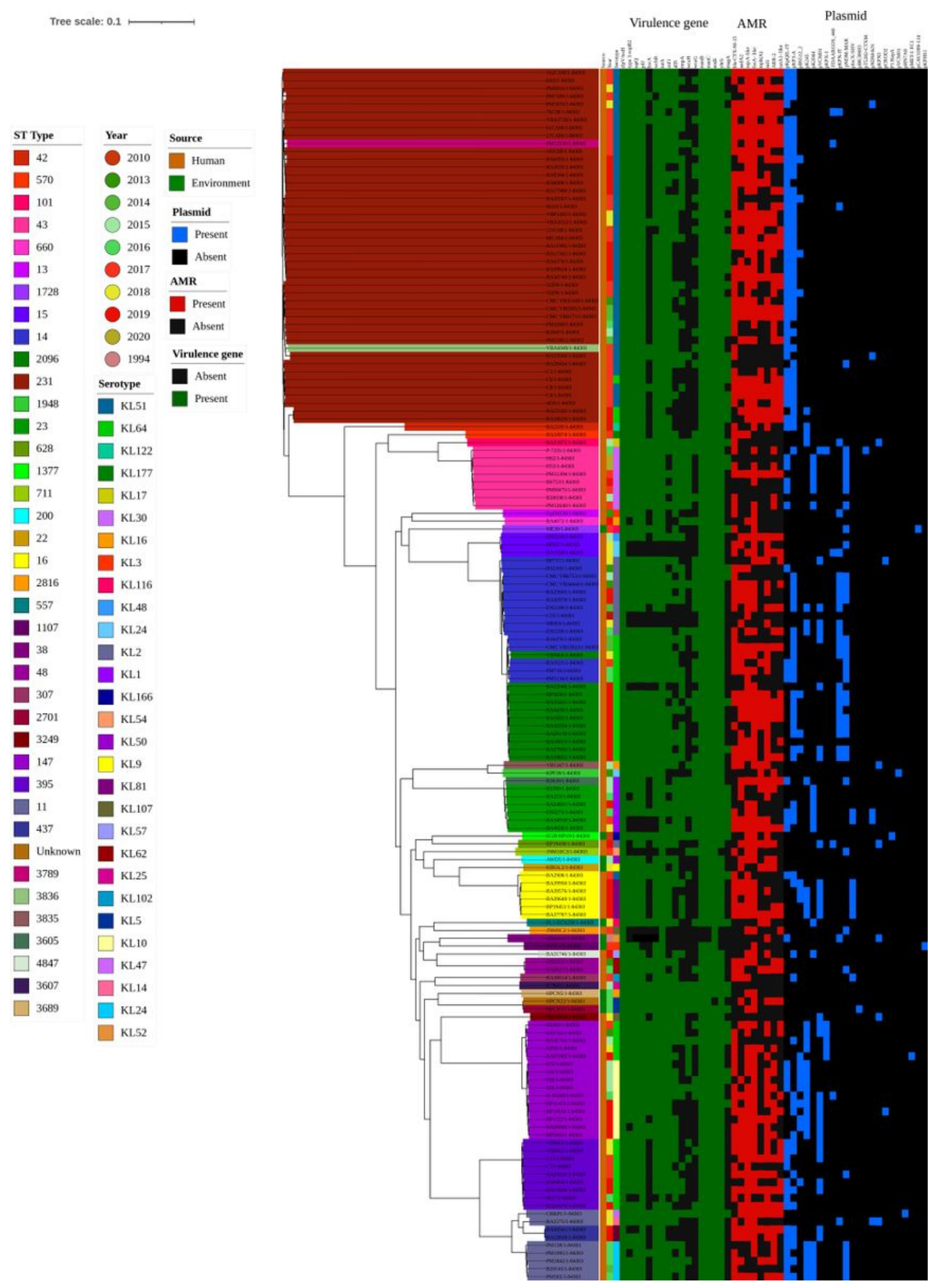

\section{Figure 6}

A complete picture of SNP based phylogeny. The tree consists of diverse STs and a few major STs that were more frequent in the clinical strains and uncommon STs are environmental strains. Colour of each branch denotes particular sequence typing. The isolation year, source, serotype is indicated by different colours. The presence of AMR genes, Virulence genes and replicon types are indicated. 


\section{Supplementary Files}

This is a list of supplementary files associated with this preprint. Click to download.

- Supplfig1.jpg

- Suppltable1.xlsx

- Suppltable2.xlsx

- suppltable3.xlsx

- suppltable4.xlsx 